\title{
Helminth parasites in two populations of Astronotus ocellatus (Cichliformes: Cichlidae) from the eastern Amazon, Northern Brazil
}

\author{
Helmintos parasitos em duas populaçóes de Astronotus ocellatus (Cichliformes: Cichlidae) da \\ Amazônia oriental, Norte do Brasil
}

\author{
Raul Henrique da Silva Pinheiro ${ }^{1,2}$ (1); Marcos Tavares-Dias ${ }^{3}$ (D); Elane Guerreiro Giese ${ }^{1,2 *}$ (D)
}

\begin{abstract}
${ }^{1}$ Programa de Pós-graduação em Biologia de Agentes Infecciosos e Parasitários, Instituto de Ciências Biológicas, Universidade Federal do Pará - UFPA, Belém, PA, Brasil

${ }^{2}$ Laboratório de Histologia e Embriologia Animal, Instituto da Saúde e Produção Animal, Universidade Federal Rural da Amazônia UFRA, Belém, PA, Brasil

${ }^{3}$ Empresa Brasileira de Pesquisa Agropecuária - EMBRAPA, Macapá, AP, Brasil
\end{abstract}

Received March 15, 2019

Accepted May 31, 2019

\begin{abstract}
This study compared the structure of helminth parasite communities in two populations of Astronotus ocellatus from two localities in Pará State, eastern Amazon (Brazil). Hosts from the Tapajós River were infected by Posthodiplostomum sp. metacercarie, larvae of Contracaecum sp. and Pseudoproleptus sp., with predominance of Contracaecum sp. Hosts from Iara Lake were infected by Procamallanus spiculastriatus, Proteocephalus sp. and Acanthocephala gen. sp., with predominance of P. spiculastriatus. Parasites had an aggregated dispersion and there were differences in Shannon diversity index and the evenness between both host populations, because the parasite component community showed no similarity. The existence of variation in infracommunity and community of parasites for $A$. ocellatus from different localities indicates the presence of an uneven distribution in terms of species and density of parasites, as well as of intermediate hosts in the localities surveyed.
\end{abstract}

Keywords: Amazon, freshwater fish, Apaiari, parasite, nematode, diversity.

\section{Resumo}

Este estudo comparou a estrutura das comunidades de helmintos parasitos em duas populaçóes de Astronotus ocellatus de duas localidades do Estado do Pará, leste da Amazônia brasileira. Hospedeiros do rio Tapajós foram infectados por Posthodiplostomum sp. metacercarie, larvas de Contracaecum sp. e Pseudoproleptus sp., com predomínio de Contracaecum sp. Hospedeiros do lago Iara foram infectados por Procamallanus spiculastriatus, Proteocephalus sp. e Acanthocephala gen. sp., com predomínio de P. spiculastriatus. Os parasitos tiveram uma dispersão agregada e houve diferenças no índice de diversidade de Shannon e na uniformidade entre as duas populaçóes hospedeiras, porque a comunidade de componentes dos parasitos não mostrou similaridade. A existência de variação nas infracomunidades e comunidades de parasitos para uma mesma espécie hospedeira de diferentes localidades indica a presença de uma distribuição desigual em termos de espécies e densidade de parasitos em $A$. ocellatus, bem como de hospedeiros intermediários nas localidades pesquisadas.

Palavras-chave: Amazônia, peixe de água doce, Apaiari, parasito, nematoda, diversidade.

\section{Introduction}

Astronotus ocellatus Agassiz, 1831 is a benthopelagic Amazonian cichlid that prefers lentic environments, finding protection under submerged branches and trunks. It is an omnivorous species, although its diet is heavily composed of fish, crustaceans, gastropods

*Corresponding author: Elane Guerreiro Giese. Laboratório de Histologia e Embriologia Animal, Instituto da Saúde e Produção Animal, Universidade Federal Rural da Amazônia - UFRA, Av. Presidente Tancredo Neves, 2501, Terra Firme, CEP 66077-830, Belém, PA, Brasil. e-mail: elane.giese@ufra.edu.br. and larvae of aquatic insects, and its behavior includes ambushing and capturing prey and avoiding predators by escaping over short distances (SOARES et al., 2011; TAVARES-DIAS \& NEVES, 2017; FROESE \& PAULY, 2019). This fish is very important as food for Amazonian riverine populations and as an ornamental fish in aquaria (SOARES et al., 2011).

Parasites provide an interesting model for studying organization and structure of parasite communities in wild fish populations 
(FRANCOVÁ \& ONDRAČKOVÁ, 2011; MARCOGLIESE et al., 2016; TAVARES-DIAS \& NEVES, 2017; OLIVEIRA et al., 2017). For A. ocellatus from the Brazil, a total of 22 parasite species has been estimated; in addition some composition and structural patterns were detected in the parasite community, such as dominance of monogenean species, dominance of ectoparasite species with crustacean infracommunities more diverse than other ectoparasites, overdispersion of ectoparasites and endoparasites, interspecific associations in the ectoparasite infracommunities, specifically a combination of generalist and specialist parasites that may contribute to host population control and correlation between parasite abundance and host total body size at the infracommunity level (TAVARES-DIAS \& NEVES, 2017). However, this is probably an underestimation of the actual diversity, due to differences in species richness of parasites for different environments, since Pinheiro et al. (2018) has recently described a new species of nematode for $A$. ocellatus from the eastern Amazon, Procamallanus spiculastriatus.

In each wild host population, the structure and composition of the parasite communities are constituted from a set of parasite species available in the environment (FRANCOVÁ \& ONDRAČKOVÁ, 2011; BITTENCOURT et al., 2014; MARCOGLIESE et al., 2016; OLIVEIRA et al., 2017; TAVARES-DIAS \& NEVES, 2017), influenced by many local factors. As a result, for the same fish species living in different environments, the component community and richness of parasites may or may not be mainly linked to environmental and climate conditions, host size, intensity of food capture by host, structure of the local food web, distance from geographic localities and availability of intermediate hosts infecting the fish populations (FRANCOVÁ \& ONDRAČKOVÁ, 2011; MARCOGLIESE et al., 2016; OLIVEIRA et al., 2017; TAVARES-DIAS \& NEVES, 2017). In addition, the type of parasite life cycle also plays an important role in environment-host-parasite interactions. The question is thus whether the component community and species richness of parasites in $A$. ocellatus populations can vary in two localities in the Brazilian Amazon. The aim of this study was to compare the structure of helminth parasite communities in two populations of $A$. ocellatus from the eastern Amazon, northern Brazil.

\section{Materials and methods}

\section{Fish and collection sites}

Forty $A$. ocellatus specimens were caught by artisanal fishermen in Tapajós River in the municipality of Santarém $\left(2^{\circ} 26^{\prime} 22^{\prime \prime} S\right.$ : $54^{\circ} 41^{\prime} 55^{\prime \prime W}$ ) (Figure 1) and forty specimens were also caught
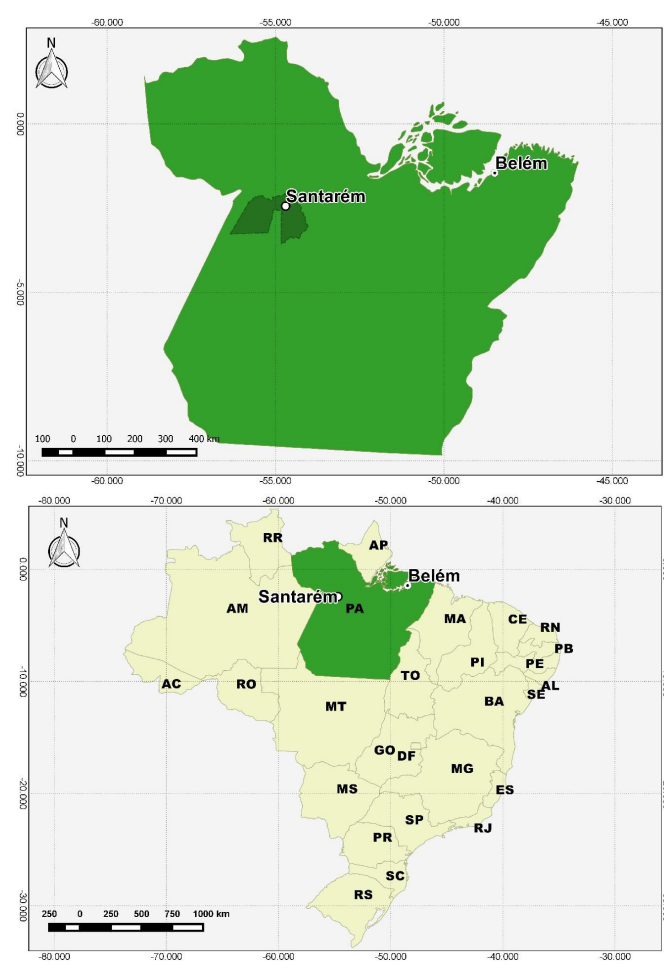

AUTOR: JEAN.L.F.SOARES

DATA:27/02/2016

SISTEMA DE REFERÊNCIAS:SIRGAS2000 BASE DE DADOS:IBAMA

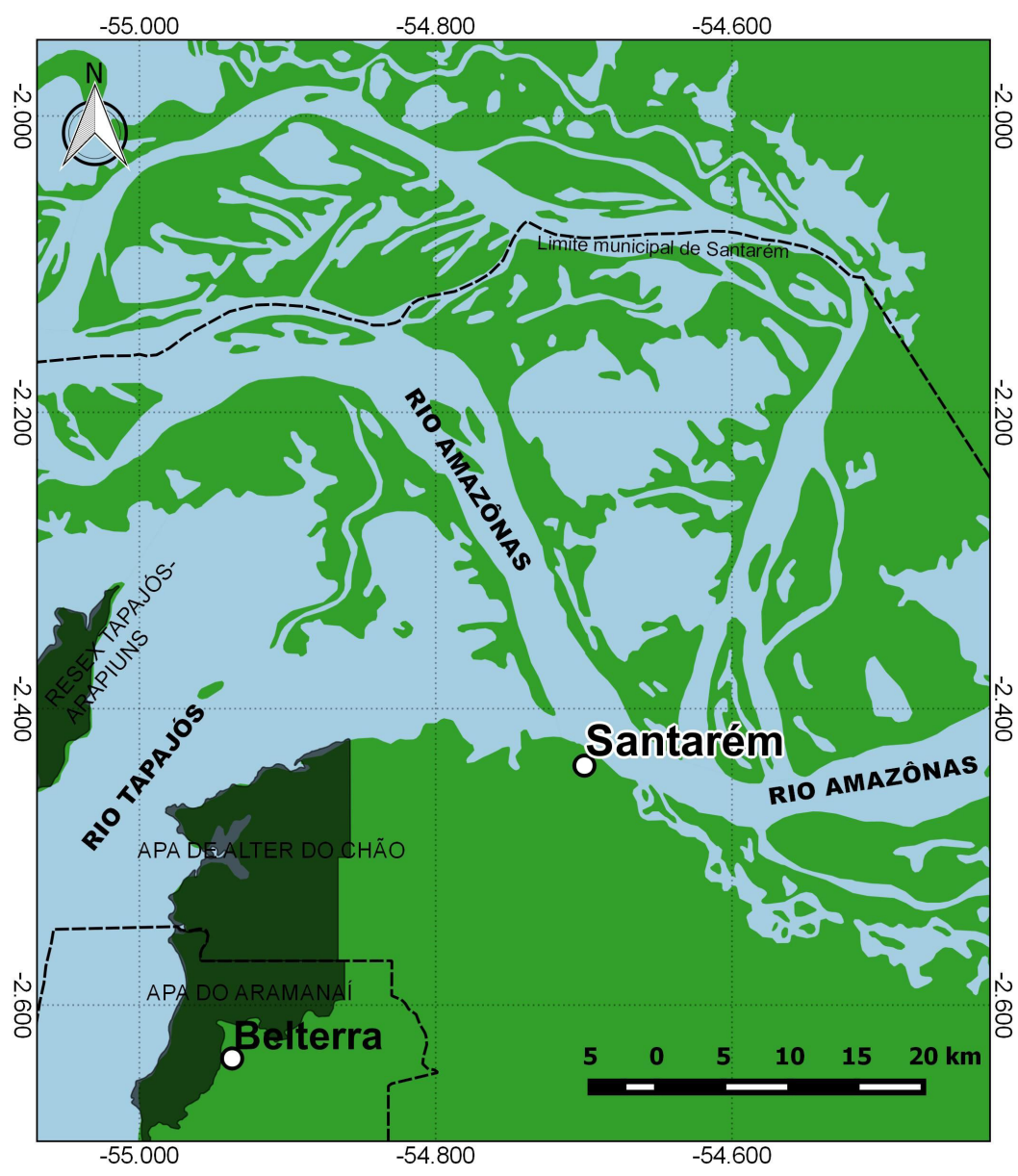

Figure 1. Collection site of Astronotus ocellatus in Tapajós River, in eastern Amazon (Brazil). 
in Iara Lake, in "Jardim Zoobotânico da Amazônia, Bosque Rodrigues Alves” (1²5’49”S, 48²7’22”W) (Figure 2) in Belém city, Pará state, both in eastern Amazon (Brazil). All procedures of fish collection were authorized by the "Instituto Chico Mendes de Conservação da Biodiversidade" (SISBIO, N 46891-1: Authentication code: 52397174).

The Tapajós River basin in region of the Pará state has an area of $221,992.98 \mathrm{~km}^{2}$ (Figure 1), and presents typical fauna and vegetation of the Amazon region, which has clear waters and extensive floodplain areas. However, this area of the Tapajós River basin is suffering from the increase of human population and environmental pressures due to the accelerated rate of devastation of forest areas and widespread changes in aquatic systems caused by pollution, silting, barrages and mining activities.

Iara Lake is located in the middle of the "Jardim Zoobotânico da Amazônia, Bosque Rodrigues Alves" (Figure 2), in the urban space of the municipality of Belém, Pará state. The "Bosque Rodrigues Alves" has a 15 ha area consisting of a remnant of primary dryland forest that shelters species of fauna and flora of the Amazon. Iara Lake is an artificial lake that has around $1500 \mathrm{~m}^{3}$ and is populated by different species of fish, including A. ocellatus (LUZ et al., 2012). All the runoff from the rains in the "Bosque Rodrigues Alves" is discharged into this lake, which has no presence of aquatic vegetation.

\section{Procedures of collection and analysis of parasites}

The fish were transported in an isothermic box with ice to the "Laboratório de Histologia e Embriologia Animal", "Instituto da Saúde e Produção Animal”, "Universidade Federal Rural da Amazônia”, "Campus Belém” for necropsy. After biometric analyses, the animals were necropsied for helminths. The gills were examined for the presence of ectoparasites, and the digestive tract (oesophagus, stomach, caeca and intestine), for the presence of endoparasites. The gastrointestinal tract of each fish was isolated in Petri dishes containing $\mathrm{NaCl}(0.9 \%)$ solution and analyzed using a stereomicroscope (LEICA-ES2). The collection, fixation, counting, preparation and staining of parasites for identification followed previous recommendations of Eiras et al. (2006).

\section{Data analysis}

The ecological terms (prevalence and mean abundance) used followed previous recommendations of Bush et al. (1997). The following descriptors for the parasite community were calculated: species richness, Shannon diversity index $(H)$, evenness $(E)$ in association with diversity index, and dominance frequency (percentage of infracommunities in which a parasite species is numerically dominant) (ROHDE et al., 1995; MAGURRAN, 2004), using the Diversity
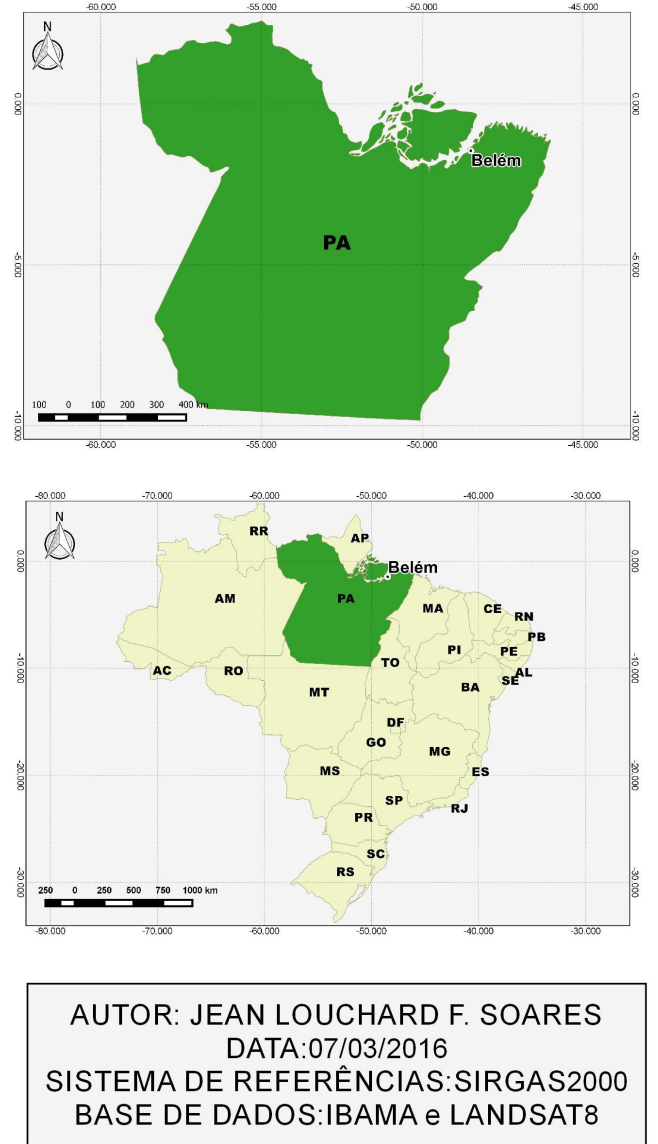

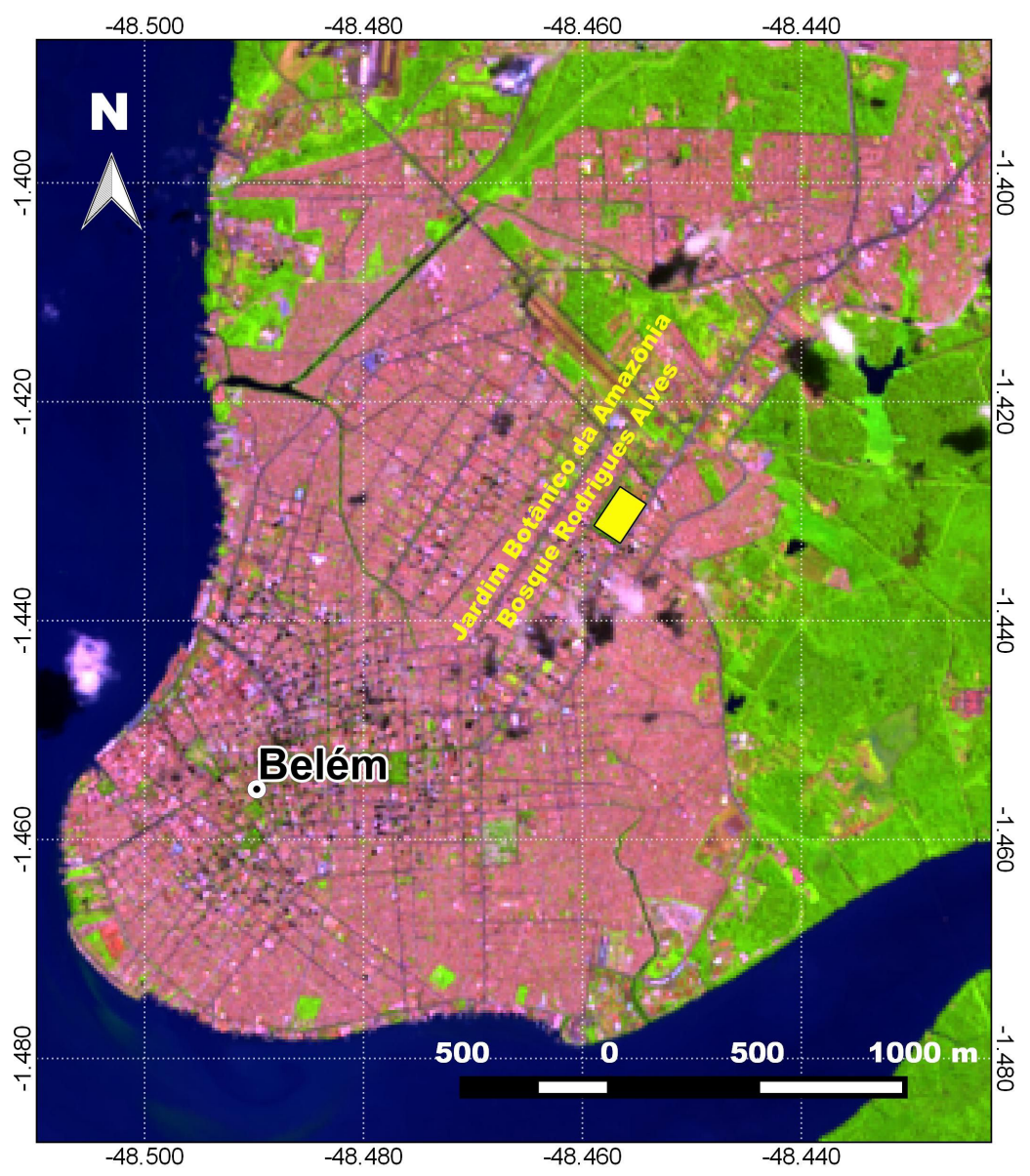

Figure 2. Collection site of Astronotus ocellatus in Iara Lake, in eastern Amazon (Brazil). 
software (Pisces Conservation Ltd., UK). The Shapiro-Wilk test was used to determine whether parasite abundance data followed a normal distribution pattern. Differences of length and weight of hosts between years and rainy and dry seasons were evaluated using the Mann-Whitney test (ZAR, 2010). The dispersion index (ID) and discrepancy index (D) were calculated using the Quantitative Parasitology 3.0 software, in order to detect the distribution pattern of the parasite infracommunities (RÓZSA et al., 2000), for species with prevalence $>10 \%$ (BUSH et al., 1990). The significance of ID, for each infracommunity, was tested using the $d$-statistics (LUDWIG \& REYNOLDS, 1988).

Differences in similarity of the parasite component communities were tested using the analysis of similarities (ANOSIM), between the localities. ANOSIM was based on ranked matrixes, generated from Jaccard index and Bray-Curtis distance (MAGURRAN, 2004), with 10,000 permutations.

\section{Results}

All parasite species in both localities were found in intestine of hosts and only metacercariae of Posthodiplostomum sp. (Diplostomidae) were found in gills. In addition, in cists of Nematoda and Cestoda were also found $37.5 \%$ of fish of Tapajós River, which were not quantified.

In hosts from the Tapajós River Posthodiplostomum sp., Contracaecum sp. (Anisakidae) and Pseudoproleptus sp. (Cystidicolidae) were found, but the dominance was of Contracaecum sp. larvae. In hosts from the Iara Lake Procamallanus spiculastriatus Pinheiro, Melo, Monks, Santos \& Giese, 2018 (Camallanidae); Proteocephalus sp. (Proteocephalidae) and Acanthocephala gen. sp. were found, but the dominance was of P. spiculastriatus (Table 1). The parasites had an aggregated dispersion pattern (Table 2).
The results showed that $85.0 \%$ of the Tapajós River fish and $65.0 \%$ of the fish of Lake Iara had parasites of one or more species of helminth. The component communities of parasites of both localities presented differentiated characteristics (Table 3). Thus, there was no similarity in comparing the component communities of both localities (Jaccard index: $\mathrm{R}=0.31, \mathrm{p}=0.0001$ and (Bray-Curtis index, $\mathrm{R}=0.27, \mathrm{p}=0.0001$ ).

The size of the hosts of the Tapajós River was smaller than that of Iara Lake. However, host weight, species richness of parasites, Shannon diversity and evenness were similar for hosts of both localities (Table 4).

In the Tapajós River there was a predominance of hosts parasitized by one species of helminths, while in Iara Lake there was a predominance of hosts parasitized by 0 to 2 species (Figure 3).

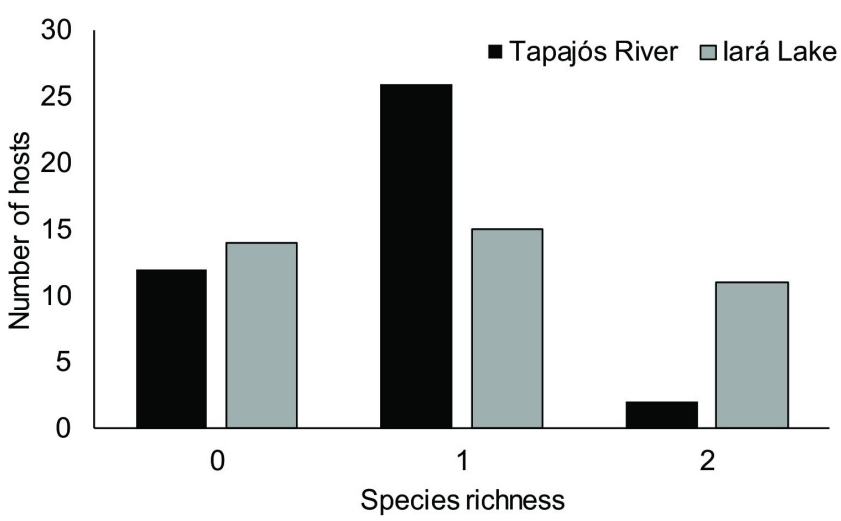

Figure 3. Species richness of helminth parasites in Astronotus ocellatus in eastern Amazon (Brazil).

Table 1. Helminth parasites in two populations of Astronotus ocellatus in eastern Amazon (Brazil).

\begin{tabular}{|c|c|c|c|c|c|c|c|c|c|c|}
\hline \multirow{2}{*}{ Species of parasites } & \multicolumn{5}{|c|}{ Tapajós River $(n=40)$} & \multicolumn{5}{|c|}{ Iara Lake $(n=40)$} \\
\hline & $\mathbf{P}(\%)$ & $\mathrm{MI} \pm \mathrm{SD}$ & $\mathrm{MA} \pm \mathrm{SD}$ & TNP & FD (\%) & $\mathbf{P}(\%)$ & $\mathrm{MI} \pm \mathrm{SD}$ & $\mathrm{MA} \pm \mathrm{SD}$ & TNP & FD (\%) \\
\hline $\begin{array}{l}\text { Posthodiplostomum sp. } \\
\text { (metacercariae) }\end{array}$ & 5.0 & $1.5 \pm 0.7$ & $0.08 \pm 0.3$ & 3 & 1 & 0 & 0 & 0 & 0 & 0 \\
\hline Contracaecum sp. (larvae) & 55.0 & $9.0 \pm 4.2$ & $5.0 \pm 5.5$ & 199 & 75 & 0 & 0 & 0 & 0 & 0 \\
\hline Pseudoproleptus sp. (larvae) & 12.5 & $12.4 \pm 2.7$ & $1.6 \pm 3.9$ & 62 & 23 & 0 & 0 & 0 & 0 & 0 \\
\hline Procamallanus spiculastriatus & 0 & 0 & 0 & 0 & 0 & 57.5 & $15.1 \pm 14.7$ & $8.7 \pm 13.4$ & 347 & 67 \\
\hline Proteocephalus sp. (larvae) & 0 & 0 & 0 & 0 & 0 & 32.5 & $13.3 \pm 16.0$ & $4.3 \pm 10.9$ & 173 & 33 \\
\hline $\begin{array}{l}\text { Acanthocephala gen. sp. } \\
\text { (cystacanths) }\end{array}$ & 0 & 0 & 0 & 0 & 0 & 2.5 & $1.0 \pm 0$ & $0.03 \pm 0.2$ & 1 & 0.2 \\
\hline
\end{tabular}

P: Prevalence, MI: Mean intensity, MA: Mean abundance, SD: Standard deviation, TNP: Total number of parasites, FD: Frequency of dominance.

Table 2. Dispersion index (ID), statistic- $d$ and discrepancy index (D) for the parasites infracommunities in Astronotus ocellatus in eastern Amazon (Brazil).

\begin{tabular}{lcccc}
\hline \multicolumn{1}{c}{ Species of parasites } & ID & $\boldsymbol{d}$ & D & Type of dispersion \\
\hline Contracaecum sp. & 2.660 & 6.60 & 0.582 & Aggregated \\
Pseudoproleptus sp. & 2.909 & 4.96 & 0.862 & Aggregated \\
Procamallanus spiculastriatus & 2.930 & 7.31 & 0.573 & Aggregated \\
Proteocephalus sp. & 2.950 & 7.34 & 0.764 & Aggregated \\
\hline
\end{tabular}




\section{Discussion}

As parasite community structure is influenced by abiotic factors within a particular habitat, the parasite community structure of a same host species may vary between populations depending on its geographical occurrence and differences in environments (FRANCOVÁ \& ONDRAČKOVÁ, 2011; MARCOGLIESE et al., 2016; OLIVEIRA et al., 2017). Although the environment of the artificial Iara Lake is a reduced environment lacking aquatic vegetation, the parasite community of $A$. ocellatus was characterized by 1 species of Nematoda, 1 Cestoda and 1 Acanthocephala, while the Tapajós River community of parasites was characterized by 1 species of Digenea and 2 Nematoda. The Tapajós River is a highly complex system and its regulation is a process that affects the integrity of the river-floodplain system. However, Tapajós River basin is suffering from the increase of human population and environmental pressures due to the accelerated rate of devastation of forest areas and widespread changes in aquatic systems caused by pollution, silting, barrages and mining activities. Thus, a dissimilarity between the component communities of both localities was expected. Therefore, in the localities of this study, $A$. ocellatus plays an important role in the life cycle and distribution of these endoparasites. In addition, environmental differences are good predictors of dissimilarity between component communities of parasites between both the populations of $A$. ocellatus.

We observe also differences in parasites component communities of $A$. ocellatus and Shannon diversity index and evenness between the both localities that might have been caused by different factors linked to host size, geographic distance between host populations, and environmental characteristics, such as water

Table 3. Component communities of helminth parasites in two populations of Astronotus ocellatus in eastern Amazon (Brazil).

\begin{tabular}{lcc}
\hline \multicolumn{1}{c}{ Characteristics } & Tapajós River & Iara Lake \\
\hline Number of examined hosts & 40 & 40 \\
Prevalence (\%) of parasites & 85.0 & 65.0 \\
Total number of parasites & 279 & 521 \\
Species of ectoparasites & 1 & 0 \\
Percentage of ectoparasites & 20.0 & 0 \\
Species of ectoparasites (larvae) & 1 & 0 \\
Species of endoparasites & 2 & 3 \\
Percentage of endoparasites & 66.7 & 100 \\
Species of endoparasites (adults) & 0 & 1 \\
Species of endoparasites (larvae) & 2 & 2 \\
\hline
\end{tabular}

quality, among other factors. In addition, hosts from the Tapajós River had only species of generalist parasites, i.e. they infect many fish species in eastern Amazon (BITTENCOURT et al., 2014; OLIVEIRA et al., 2017; TAVARES-DIAS \& NEVES, 2017). In addition, the absence or presence of these endoparasite species in hosts of both localities may be mainly related to differences in host diet, absence or unviability of infective stages and viability of adequate intermediate hosts between both environments (MARCOGLIESE et al., 2016; TAVARES-DIAS \& NEVES, 2017; OLIVEIRA et al., 2017).

The infracommunities of parasites of a same species of host from different localities can vary depending on its geographical distance and on differences in habitat and parasite abundance, which can be influenced by biotic (e.g. presence of infective stages and ingested food preys, etc.) and abiotic (e.g. environment quality, temperature, precipitation levels, etc.) factors (FRANCOVÁ \& ONDRAČKOVÁ, 2011; MARCOGLIESE et al., 2016; OLIVEIRA et al., 2017). In A. ocellatus, the helminths of hosts from the Tapajós River were Posthodiplostomum sp., Contracaecum sp. and Pseudoproleptus sp., with dominance of Contracaecum sp., while helminths of hosts from the Iara Lake were P. spiculastriatus, Proteocephalus sp. and Acanthocephala gen. sp., with dominance of $P$. spiculastriatus. Parasites had an overdispersion, a common distribution pattern in A. ocellatus (TAVARES-DIAS \& NEVES, 2017). Furthermore, as the population of $A$. ocellatus from the Iara Lake consisted of larger (older) individuals than the population of hosts from the Tapajós River, it usually could ingest more infective larvae, either directly from the intermediate host or from paratenic hosts, with the increased volume of food consumed by larger fish. Therefore, A. ocellatus are ingesting infective stages, either in artificial and natural environment.

Life cycles of the Posthodiplostomum species involve two intermediate hosts, a snail and a fish species, besides a definitive host, a piscivorous bird species (RITOSSA et al., 2013). Contracaecum species use several species of fish as intermediate or paratenic hosts due to their lack of parasitic host specificity, but in general are found in fish-eating birds and piscivorous fish in the adult stages. The fish that act as intermediate hosts acquire this parasite by predation on smaller fish, which in turn become infected by ingesting copepods, gastropods, mollusks, coelenterates or ctenophores that contain infective forms, or when they directly acquire the larvae of Contracaecum sp. in their free life stage (OLIVEIRA et al., 2017; PINHEIRO et al., 2019). Metacercariae of Posthodiplostomum sp. and Contracaecum sp. larvae are frequent parasites in fish species from the eastern Amazon because they use several species of fish

Table 4. Body and diversity parameters for the helminth parasites communities in two populations of Astronotus ocellatus in eastern Amazon (Brazil).

\begin{tabular}{|c|c|c|c|c|c|c|}
\hline \multirow{2}{*}{ Parameters } & \multicolumn{2}{|c|}{ Tapajós River } & \multirow{2}{*}{ Median } & \multirow{2}{*}{$\begin{array}{c}\text { Iara Lake } \\
\text { 25-75 Percentiles } \\
\end{array}$} & \multirow{2}{*}{$U$} & \multirow{2}{*}{ p-value } \\
\hline & Median & 25-75 Percentile & & & & \\
\hline Length $(\mathrm{cm})$ & 24.0 & $21.8-24.5$ & 24.6 & $24.0-26.1$ & 468.0 & 0.001 \\
\hline Weight (g) & 375.2 & $329.9-401.0$ & 339.8 & $279.2-396.2$ & 681.5 & 0.25 \\
\hline Species richness & 1.0 & $0.0001-1.0$ & 1.0 & $0.0001-2.0$ & 700.5 & 0.34 \\
\hline Shannon index $(H)$ & 0.0001 & $0.0001-0.001$ & 0.0001 & $0.0001-0.3$ & 613.5 & 0.07 \\
\hline Evenness $(E)$ & 0.0001 & 0.0001-0.001 & 0.0001 & $0.0001-0.3$ & 613.5 & 0.07 \\
\hline
\end{tabular}

U: Mann-Whitney test 
as hosts due to their lack of parasitic host specificity, including A. ocellatus (BITTENCOURT et al., 2014; OLIVEIRA et al., 2017; TAVARES-DIAS \& NEVES, 2017). Contracaecum sp., a parasite with zoonotic potential for humans (PINHEIRO et al., 2019), was present in A. ocellatus from the Tapajós River in higher prevalence and low abundance, while Posthodiplostomum sp. had a low prevalence and abundance. In addition, $A$. ocellatus population had larvae of Pseudoproleptus sp., which have been reported in the cichlid Satanoperca jurupari, a paratenic host of this nematode species because the prawn Macrobrachium amazonicum is a first intermediate host in the Amazon River delta (MELO et al., 2011). However, P. spiculastriatus, a nematode recently described in A. ocellatus from Iara Lake (PINHEIRO et al., 2018), still has an unknown life cycle.

Procercoids of Proteocephalus sp. were found in only A. ocellatus from Iara Lake. However, only Proteocephalus gibsoni Rego \& Pavanelli 1990 is known to infect $A$. ocellatus from the Amazon (TAVARES-DIAS \& NEVES, 2017). Planktonic crustaceans diaptomid or cyclopoid copepods serve as intermediate hosts of the Proteocephalus species. Metacestodes or plerocercoids develop in the body cavity of these crustaceans and the definitive host, a fish, becomes infected directly after consuming them (SCHOLZ, 1999). Undetermined cystacanths of acanthocephalans were also found in A. ocellatus from Iara Lake. Acanthocephalans are obligatory endoparasites that utilize arthropods and vertebrates to complete their complex life cycle; thus, adult parasites are found in a variety of vertebrates, including fish, birds and mammals (SCHMIDT \& HUGGHINS, 1973; KENNEDY, 2006).

In summary, communities of helminths in $A$. ocellatus of both localities were characterized by moderate prevalence and low abundance with low parasite species richness, low diversity, low evenness and overdispersion. Lastly, the community of helminth parasites in both populations of $A$. ocellatus were not similar as expected, and parasite diversity was the factor causing differences in the parasitic community.

\section{Acknowledgements}

This study was financed in part by the "Coordenação de Aperfeiçoamento de Pessoal de Nível Superior - Brasil” (CAPES) Finance Code 001, "Universidade Federal do Pará" and "Ministério da Educação do Brasil". This study is part of the Ph.D. thesis of Raul Henrique da Silva Pinheiro, developed for the "Programa de Pós-Graduação em Biologia de Agentes Infecciosos e Parasitários”, "Instituto de Ciências Biológicas, Universidade Federal do Pará" (UFPA). Marcos Tavares-Dias was supported by a research fellowship from the "Conselho Nacional de Pesquisa e Desenvolvimento Tecnologico” (CNPq, Brazil) (\# 303013/2015-0).

\section{References}

Bittencourt LS, Pinheiro DA, Cárdenas MQ, Fernandes BMM, TavaresDias M. Parasites of native Cichlidae populations and invasive Oreochromis niloticus (Linnaeus 1758) in tributary of Amazonas River (Brazil). Rev Bras Parasitol Vet 2014; 23(1): 44-54. http://dx.doi.org/10.1590/ S1984-29612014006. PMid:24728360.
Bush AO, Lafferty KD, Lotz JM, Shostak AW. Parasitology meets ecology on its own terms: Margolis et al. revisited. J Parasitol 1997; 83(4): 575583. http://dx.doi.org/10.2307/3284227. PMid:9267395.

Bush AO, Aho JM, Kennedy CR. Ecological versus phylogenetic determinants of helminth parasite community richness. Evol Ecol 1990; 4(1): 1-20. http://dx.doi.org/10.1007/BF02270711.

Eiras JC, Takemoto RM, Pavanelli GC. Métodos de estudo e técnicas laboratoriais em parasitologia de peixes. Maringá: Eduem; 2006.

Francová K, Ondračková M. Host-parasite interactions in sympatric and allopatric populations of European bitterling. Parasitol Res 2011 109(3): 801-808. http://dx.doi.org/10.1007/s00436-011-2326-3. PMid:21431383.

Froese R, Pauly D, editors. FishBase [online]. Mumbai: FishBase Team; 2019 [cited 2019 Feb 10]. Available from: www.fishbase.org

Kennedy CR. Ecology of the Acanthocephala. New York: Cambridge University Press; 2006. http://dx.doi.org/10.1017/CBO9780511541902.

Ludwig JA, Reynolds JF. Statistical ecology: a primer on methods and computing. New York: Wiley-Interscience Pub; 1988.

Luz ML, Arraes RRM, Oliveira S. Educação ambiental em áreas verdes urbanas como recurso didático para o ensino de biogeografia. Rev Geonorte 2012; 3(4): 171-177.

Magurran AE. Measuring biological diversity. Oxford: Blackwell Publishing; 2004.

Marcogliese DJ, Locke SA, Gelinas M, Gendron AD. Variation in parasite communities in spottail shiners (Notropis hudsonius) linked with precipitation. J Parasitol 2016; 102(1): 27-36. http://dx.doi. org/10.1645/12-31. PMid:26465386.

Melo MF, Giese EG, Santos JN, Santos CP. First record of Pseudoproleptus sp. (Nematoda: Cystidicolidae) in fish host. Acta Trop 2011; 117(3): 212-215. http://dx.doi.org/10.1016/j.actatropica.2010.12.011. PMid:21187054.

Oliveira MSB, Gonçalves RA, Ferreira DO, Pinheiro DA, Neves LR, Dias MKR, et al. Metazoan parasite communities of wild Leporinus friderici (Characiformes: Anostomidae) from Amazon River system in Brazil. Stud Neotrop Fauna Environ 2017; 52(2): 146-156. http://dx.doi.org/1 0.1080/01650521.2017.1312776.

Pinheiro RHS, Furtado AP, Santos JN, Giese EG. Contracaecum larvae: morphological and morphometric retrospective analysis, biogeography and zoonotic risk in the amazon. Rev Bras Parasitol Vet 2019; 28(1): 12-32. http://dx.doi.org/10.1590/s1984-29612019002. PMid:30892463.

Pinheiro RHS, Melo FTV, Monks S, Santos JN, Giese EG. A new species of Procamallanus Baylis, 1923 (Nematoda, Camallanidae) from Astronotus ocellatus (Agassiz, 1831) (Perciformes, Cichlidae) in Brazil. ZooKeys 2018; 790(790): 21-33. http://dx.doi.org/10.3897/zookeys.790.24745. PMid:30364795.

Ritossa L, Flores VR, Viozzi G. Life-cycle of a Posthodiplostomum species (Digenea: Diplostomidae) from Patagonia, Argentina. J Parasitol 2013; 99(5): 777-780. http://dx.doi.org/10.1645/12-170.1. PMid:23628085.

Rohde K, Hayward C, Heap M. Aspects of the ecology of metazoan ectoparasites of marine fishes. Int J Parasitol 1995; 25(8): 945-970. http://dx.doi.org/10.1016/0020-7519(95)00015-T. PMid:8550295. 
Rózsa L, Reiczigel J, Majoros G. Quantifying parasites in samples of hosts. J Parasitol 2000; 86(2): 228-232. http://dx.doi.org/10.1645/00223395(2000)086[0228:QPISOH]2.0.CO;2. PMid:10780537.

Schmidt GD, Hugghins EJ. Acanthocephala of South American Fishes. Part I, Eoacanthocephala. J Parasitol 1973; 59(5): 829-835. http://dx.doi. org/10.2307/3278417.

Scholz T. Life cycles of species of Proteocephalus, parasites of fishes in the Palearctic region: a review. J Helminthol 1999; 73(1): 1-19. http://dx.doi. org/10.1017/S0022149X99000013. PMid:10431368.
Soares MGM, Costa EL, Siqueira-Souza FK, Anjos HDB, Yamamoto KC, Freitas CEC. Peixes de lagos do médio Rio Solimóes. 2a ed. Manaus: Reggo Ediçóes; 2011.

Tavares-Dias M, Neves LR. Diversity of parasites in wild Astronotus ocellatus (Perciformes, Cichlidae), an ornamental and food fish in Brazil. An Acad Bras Cienc 2017;89(3 Suppl): 2305-2315. http://dx.doi. org/10.1590/0001-3765201720160700. PMid:29044314.

Zar JH. Biostatistical analysis. $5^{\text {th }}$ ed. New Jersey: Prentice Hall; 2010. 